\title{
GUIDELINES FOR THE REHABILITATION OF THE HOUSING ESTATE WITH THE CPTED STRATEGY
}

\begin{abstract}
Contemporary urbanists and architects are faced with the problem of adapting degraded post-communist neighbourhoods to the current needs of their inhabitants. Most of those housing estates need rehabilitation which is understood as an aspiration for reconstruction of settlement's range as a human-friendly environment and regain it's lost values. A CPTED strategy could be very helpful to define guidelines for the rehabilitation. Based on Crime Prevention through Environmental Design strategy the features of space like natural surveillance, space clarity, territoriality, the feeling of responsibility for public space and management can affect it's quality. These aspects were very useful set of criteria for the author to try to express guidelines for the rehabilitation of the housing estate in Pabianice. Methods used in the research included physical inventory of the neighbourhood and questionnaire survey among the sample of 100 inhabitants of the analysed area. Conclusions from the use of both mentioned methods are well supplementing each other and are pointing the most severe spatil and social problems in the area. This how the environment of the housing estate looks like in the eyes of it's inhabitants and visitors were crucial while shaping guidelines for rehabilitation.
\end{abstract}

Keywords: Rehabilitation, housing estate, CPTED strategy, physical inventory, survey research, Pabianice, post-communist housing estate, neighbourhood, safe environment, blocks of flats, living quality.

\section{Introduction}

Neighbourhoods built of blocks of flats are very common in almost every Polish city or town. They are inhabited by millions of people of different wealth or social status and living in such dwellings is standard in Poland. These settlements - the legacy of communism - have different infrastructures and functional programmes which stems from the economical conditions that change over the years. The standard of living in blocks of flats depends on the quality of workmanship and their future improvements. Housing estates, built as a housing back-up for 
the national industry, have mostly degraded after the fall of some national factories. These processes, which contributed to the lack of workplaces, combined with the impossibility to frequently change a place of living, created pathological socio-spatial structures. Post-communist neighbourhoods are frequently unable to provide people with a functional programme which would satisfy their needs (Basista 2001). Therefore, the housing estates built in the second half of the $20^{\text {th }}$ century require rehabilitation. Contemporary urbanists and architects are faced with adapting these neighbourhoods to the needs of their inhabitants and creating places with favourable living conditions.

\section{Methods used}

One of such post-communist housing estates is the subject of this analysis, which aims to present spatial development of the neighbourhood over the years and try to determine guidelines for its rehabilitation. While implementing rehabilitation activities there is a need of making certain premises and using appropriate methods. Rehabilitation is understood as an aspiration for reconstruction of settlement's range as a human-friendly environment and regain it's lost values (Chmielewski, Mirecka 2001). A very useful strategy to draw guidelines for rehabilitation could be CPTED strategy. CPTED is an acronym for Crime Prevention through Environmental Design what means appropriate design of urban environment and it's effective usage that can lead to crime and crime-caused fear reduction and increase of standard of living (Cozens 2014).

Based on the CPTED strategy, the following features of space can affect its quality:

- natural surveillance,

- space clarity,

- territoriality,

- the feeling of responsibility for public space,

- management (Mączka 2012; Wieteska-Rosiak 2014).

All these above-mentioned aspects can be a useful set of criteria during a physical inventory of the area or a survey, both of which are methods used by the author to analyse spatial structure and quality of life in the neighbourhood and draw conclusions.

The physical inventory was made by the author on the area of the neighbourhood which is a subject of the rehabilitation. This inventory was made with the use of inventory table where according to CPTED strategy the following features of environment were judged:

- spatial development (infrastructure),

- possibility of surveillance, 
- space legibility,

- visibility of the ownership in space,

- technical condition of infrastructure (Lake 2007).

The second method used by the author to recognize inhabitants opinions about the housing estate they live in was questionnaire survey research. Statistical sample at the number of 100 people consisted of inhabitants of blocks of flats in the area of interest. The questionnaire included three questions which asked respondents for:

- their opinion of the neighbourhood according to standard of living and the subjective level of safety,

- their judge about possible problems in the neighbourhood and to point where they appear if so,

- proposals of necessary changes in the area.

\section{History and spatial development}

The neighbourhood which is the subject of these analysis is located in the western part of Pabianice near the town centre. The examined area is surrounded by Zamkowa Street, Wyszyńskiego Street, Skłodowskiej-Curie Street and Konopnickiej Street. This place was originally developed into a housing complex built for the workers of the cotton products factory. The urban structure, including 20 single-storey houses made of brick and a school, was set up at the end of the $19^{\text {th }}$ century by the Krusche and Ender factory. That neighbourhood covered half of the area of the current housing estate (Brzeziński, Gramsz 2004; Adamczyk 2007).

Today, the area of the housing estate is dominated by 4- to 11-storeyed habitable buildings. There are numerous service points located along Zamkowa Street which is considered a local „centre of activity”. Services like a grocer's, a supermarket, a church, a hairdresser, a ground school and others can be found there. The space between blocks of flats is occupied by car parks and greenery (trees and grass). The green areas are interspersed with fenced playgrounds. The locals use the lanes between the blocks of flats, or the driveways, as well as the sides of main streets to park their vehicles. Most of the streets in the area have asphalt surfaces except driveway lanes and Zamkowa Street - those are still covered with old cobblestone. Zamkowa Street also has a tramway track. All these elements of spatial development influence both the functioning of the neighbourhood and its image. The situational plan of the housing estate is presented in the picture (Fig. 1). 


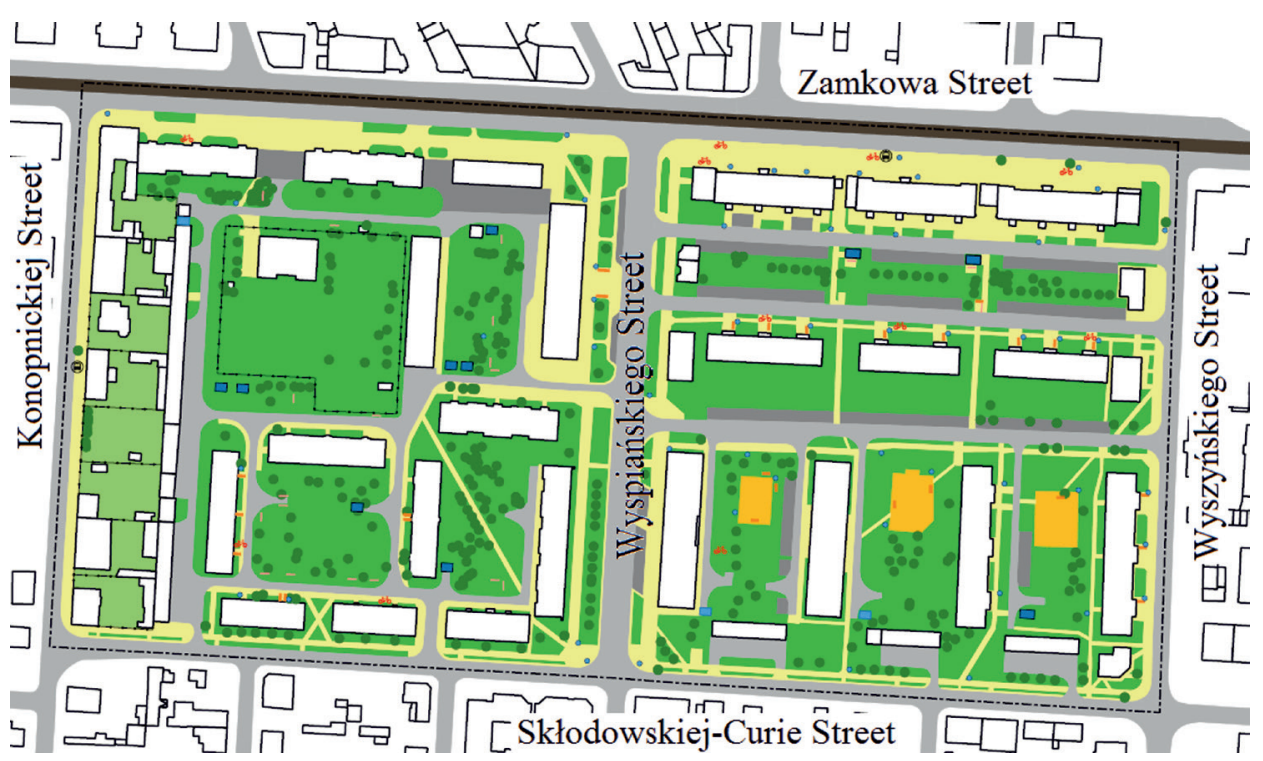

Fig. 1. Situational plan of the housing estate in Pabianice

Source: own, based on basic map and physical inventory

\section{Physical inventory conclusions}

The natural surveillance in the analysed area is limited because of groups of trees which restrict the view of areas between blocks of flats. Additionally in the eastern part of the area appears several gable ends which reduce passive surveillance as a result of the leak of windows in buildings' gables. Another problem is the lighting of the area which is inaccurate. However there are lamps above the enters to the buildings they are not efficient enough to lighten areas between blocks of flats.

The neighbourhood seems to be isolated from the rest of the surroundings in terms of connection the inside of the neighbourhood structure with the communication strings. Moreover the view on the Saint Mary's Church which stands for the local dominant is reduced by high-rise blocks of flats. That all means the space legibility does not allow those users of the space, who do not know exactly the urban structure of the neighbourhood, to know his accurate localization.

The walls of the blocks of flats are the formal borders between public and private space - with public space outside the buildings and private space - inside. However, the areas around blocks of flats are not visibly ascribed to either category. This issue concerns the whole neighbourhood, but in several places in the western part of the area there are little gardens underneath the windows which are the beginnings of semi-private space. There can be seen a dependence that the more 
intensive the building is, the smaller is identification with the neighbourhood and responsibility for the common space among inhabitants.

In the neighbourhood, there are also numerous places in a bad technical condition. One of them is the majority of infrastructure in western part of the housing estate. Another, very significant, is Zamkowa Street with its old cobblestone road surface and driveway lanes also covered with cobblestone. This kind of road surface when it is neglected is a considerable noise generator and affects destructively on vehicles driving by. The greenery also requires maintenance as it covers quite a lot of area and is full of unused potential.

Basing on the physical inventory two zones with a bit more different characteristics can be separated. The western with older and lower intensity building and the newer with higher, up to 11-storeyed blocks of flats. The border between these zones makes Wyspiańskiego Street.

The conclusions from questionnaire survey research are reflected in the physical state of the housing estate. The residents who participated in the survey also mentioned inaccurate lighting of the housing estate. In their opinion this is especially noticeable in the eastern part of the neighbourhood. The fact that people identify with the area is more visible in the western part than in the eastern one. A lower intensity of a building development is a positive quality, which can be supported by the example of little gardens, filled with greenery and flowers, near older blocks of flats. Zamkowa Street is a kind of a "centre of activity" because it is an axis on which many services cluster. Respondents confirmed that access to services available in the neighbourhood is a positive quality. However, movement in the area between buildings in the middle of the housing estate is sparse, because of a lack of movement generators. This results in a feeling that the inside of the housing estate is partially abandoned.

\section{The survey research conclusions}

What is more people do not feel very safe in that area. This can be due to the problems noticeable in the neighbourhood. According to the survey, drunk people on the streets, of whom women are mostly afraid, appear to be the biggest problem. The issue is dominating only in the eastern part of the housing estate and appears to be related to the close location of a bar, a pub and a liquor store near Wyspiańskiego Street. Other important problems mentioned by respondents were trashing of the area, dog issue, bad technical condition of the road surface and small possibilities to spend their free time.

Inhabitants taking part in the survey had an opportunity to propose their solutions on the neighbourhood. People aged $65+$ constituted the majority of the respondents. That was probably the reason why putting benches around the blocks of flats was high on the list of their requirements. The second most needed 
thing according to the survey is more greenery. This suggestion can be surprising because of huge amount of trees and grass between the buildings. However this greenery is badly managed but it has a big potential and needs to regain utility function. Other changes suggested by the inhabitants included among others renewal of the blocks of flats, bigger car park and more playgrounds.

The results of survey research are a good supplement of physical inventory of the neighbourhood and are pointing which of the diagnosed problems are the most severe. This how the environment of the housing estate looks like in the eyes of it's inhabitants can be crucial while shaping guidelines for rehabilitation.

\section{Summary}

The realization of the aim of that thesis is a trial to express the guidelines for the rehabilitation of the housing estate. The main problem of this neighbourhood, inebriated people on the streets, can be solved by opening a restaurant with a limited number of alcoholic drinks on offer, near the bar. Therefore, the pub would host some meetings for the inhabitants and the restaurant would serve to encourage people to eat out and socialize. However these actions are the first steps to resolve the phenomenon of inebriated people on the streets. This problem should be still under observation by the housing council. Another issue that needs addressing is the road surface of Zamkowa Street. As the main street in town, it needs asphalt surface along its whole length. This modernisation would decrease the level of noise and increase the quality of movement along the street. Another action that should be taken is filling the area with elements of small architecture like benches, rubbish bins and bike parks. Creating places where people can meet, maintain their garden, maybe barbecue, simply play some games or talk could help in integrating inhabitants and increasing the sense of responsibility for their place of living. By giving people a chance and place to meet, maintain their surroundings and become more engaged in the neighbourhood life, the modernization of infrastructure could help create a safe, beautiful and well-maintained place about which an inhabitant could say with a smile: "I live here. This is my neighbourhood".

\section{Bibliography}

Adamczyk A., 2007, Pabianice. Przewodnik po historii i współczesności miasta, Muzeum Miasta Pabianic, Pabianice.

Basista A., 2001, Betonowe dziedzictwo. Architektura w Polsce czasów komunizmu, Wydawnictwo Naukowe PWN, Warszawa.

Brzeziński K., Gramsz A., 2004, Ulica Zamkowa w Pabianicach 1824-2004, Grako, Łódź. Chmielewski J.M., Mirecka M., 2001, Modernizacja osiedli mieszkaniowych, Oficyna Wydawnicza Politechniki Warszawskiej, Warszawa. 
Cozens P., 2014, Crime Prevention through Environmental Design (CPTED): A Review and Modern Bibliography, [in:] Property Management.

Lake T., 2007, Crime Prevention through Environmental Design. Guidelines for Queensland. Part A: Essential features of safer places, The State of Queensland.

Mączka J., 2012, CPTED - teoria, praktyka, skuteczność, [in:] Czapska J. (ed.), Zapobieganie przestępczości przez kształtowanie przestrzeni, Wydawnictwo Uniwersytetu Jagiellońskiego, Kraków.

Wieteska-Rosiak B., 2014, Kształtowanie przestrzeni publicznej z uwzględnieniem aspektów bezpieczeństwa publicznego, Biuletyn, 164, Komitet Przestrzennego Zagospodarowania Kraju PAN, http://skpzk.czasopisma.pan.pl/images/data/skpzk/wydania/ No_164_2014/15WIETESKA_ROSIAK.pdf (accessed on: 10.06.2017).

\section{WYTYCZNE DO REHABILITACJI ZESPOLU MIESZKANIOWEGO Z WYKORZYSTANIEM STRATEGII CPTED}

Zarys treści: Bloki mieszkalne są bardzo często spotykane w niemal każdym polskim dużym czy też małym mieście. Są zamieszkane przez miliony ludzi o różnym statusie majątkowym i społecznym. Mieszkanie w tego typu budynkach jest w Polsce standardem. Postkomunistyczne osiedla są najczęściej niezdolne do zapewnienia mieszkańcom programu funkcjonalnego, który zaspokoiłby ich potrzeby. Wiele z nich potrzebuje działań rehabilitacyjnych. Jednym z takich zespołów mieszkaniowych jest osiedle w Pabianicach, które jest przedmiotem niniejszego opracowania.

Do wyznaczenia wytycznych do rehabilitacji osiedla mieszkaniowego, co jest celem tego opracowania, może posłużyć strategia CPTED (zapobiegania przestępczości przez kształtowanie przestrzeni). Bazując na CPTED można wyróżnić cechy przestrzeni, które wpływają na jej jakość, a są to: możliwość obserwacji, czytelność przestrzeni, zaznaczenie granic własności w przestrzeni, poczucie odpowiedzialności za przestrzeń publiczną oraz zarządzanie, a co a tym idzie stan techniczny infrastruktury.

W celu zbadania stanu przestrzeni na analizowanym osiedlu, autor wykonał inwentaryzację terenową. Bazując na założeniach CPTED, zbadane zostały własności przestrzeni osiedla mieszkaniowego. Drugą metodą badawczą wykorzystaną przez autora była ankieta kwestionariuszowa, przeprowadzona wśród 100 mieszkańców osiedla. Dotyczyła ona opinii mieszkańców o miejscu zamieszkania, w tym subiektywnego poczucia bezpieczeństwa oraz problemów mogących wystąpić w przestrzeni.

Na podstawie inwentaryzacji terenowej zostały określone cechy przestrzeni, które nie wpływają korzystnie na jakość i poczucie bezpieczeństwa w przestrzeni. Zaliczają się do nich: ograniczona możliwość obserwacji ze względu na nieuporządkowane grupy zieleni, wrażenie izolacji przestrzeni osiedla od reszty miasta, brak wyraźnie widocznej przestrzeni półprywatnej, a także zły stan zieleni i infrastruktury, w tym budynków i nawierzchni ciągów komunikacyjnych. Biorąc pod uwagę cechy przestrzenne osiedla, można wyznaczyć podział na dwie strefy - wschodnią i zachodnią - o odmiennej charakterystyce, w tym intensywności zabudowy o układzie przestrzennym.

Wnioski z badań ankietowych znajdują swoje odbicie w stanie fizycznym osiedla mieszkaniowego. Według respondentów, pozytywnymi cechami osiedla mieszkaniowego jest przede wszystkim dostępność do usług, jak również niska intensywność zabudowy 
w zachodniej części osiedla. Mieszkańcy wskazali także problemy, które ich zdaniem występują i wymagają interwencji. Zdaniem ankietowanych wśród najważniejszych znalazły się: problem pijanych osób na ulicy, zły stan nawierzchni jezdni, zaśmiecenie obszaru, psi problem, a także skromne możliwości spędzania czasu wolnego. Respondenci zostali poproszeni o zaproponowanie zmian, które poprawiłyby jakość przestrzeni i życia na osiedlu. Najczęściej pojawiającą się sugestią było ustawienie większej ilości ławek, ale też zwiększenie, a raczej uporządkowanie zieleni na osiedlu. Wspomniano także o potrzebie remontu bloków, większym parkingu i nowych placach zabaw dla dzieci.

Badania ankietowe stanowią dobre uzupełnienie inwentaryzacji zespołu mieszkaniowego i stanowią podstawę do podjęcia próby sformułowania wytycznych do rehabilitacji osiedla w Pabianicach. Rozwiązaniem głównego problemu, czyli pijanych na ulicy, może być otworzenie w pobliżu baru, restauracji z ograniczoną ofertą napojów alkoholowych. Są to pierwsze kroki do integracji tych problemowych jednostek ze społecznością osiedla i problem ten powinien pozostać pod obserwacją rady osiedla. Istotnymi działaniami, które wydają się być niezbędne na obszarze opracowania, są m.in.: modernizacja nawierzchni ciągów komunikacyjnych, uzupełnienie obszaru obiektami małej architektury oraz stworzenie miejsc, gdzie mieszkańcy mogliby się spotkać, rozpalić grilla czy też pograć w gry. Rozwiązania te mogą pomóc w utworzeniu zadbanego i bezpiecznego osiedla, odpowiadającego potrzebom jego mieszkańców.

Słowa kluczowe: Rehabilitacja, blokowisko, osiedle mieszkaniowe, strategia CPTED, badania terenowe, badania ankietowe, Pabianice, wielkomiejski zespół mieszkaniowy, osiedle postkomunistyczne, przestrzeń bezpieczna, bloki, jakość życia.

Przemysław Cieślak, Eng.

Spatial Economy College Łódź University of Technology e-mail: przemyslaw.cieslak@interia.pl 